\title{
История и культура горских евреев
}

\author{
/ под. ред. Е.М. Назаровой, И.Г. Семенова. \\ М: Всемирный конгресс горских евреев, 2018. \\ ISBN 978-7164-0767-1. 800 c.
}

DOI: $10.31168 / 2658-3364.2020 .2 .25$

Несмотря на то, что история, культура и традиции горских евреев уже в 1990-е годы стала предметом отдельного изучения, было проведено несколько специальных конференций по этой теме, регулярно выходят статьи, фундаментальных трудов и монографий на русском языке практически нет. Единственным исключением является вышедшая в 1999 г. книга «Горские евреи: История, этнография, культура». Спустя почти 20 лет после ее издания, вышел новый труд, который объединил исследователей из России и Израиля.

Идея создать коллективную монографию возникла в 2013 г. Тогда было решено собрать большой научный коллектив и подготовить фундаментальное издание, которое стало бы развитием и продолжением работы, вышедшей в 1999 г. Как пишет в предисловии редактор монографии: «Наша книга - это сегодняшний уровень науки по истории и культуре горских евреев. Каждый наш автор - специалист в той или иной области гуманитарного знания - предлагает читателю свои личные исследовательские результаты, наработки, достижения» (С. 11).

Книга открывается предисловием научного редактора Евгении Назаровой и введением, написанным Игорем Семеновым, где он подробно рассматривает экзо- и эндо-этнонимы, используемые для горских евреев, а также пишет об истории «татского мифа». Всего в книге шесть частей. Во многом структура данного труда повторяет структуру работы 1999 г. Однако материалы не дублируют друг друга. Если в книге 1999 г. было несколько републикаций материалов конца XIX в. (например, Иуды Черного, Ильи Анисимова), то в новой монографии представлены только оригинальные статьи, которые были написаны специально для данного издания.

Первая часть «История горских евреев» открывается статьями научного редактора И.Г. Семенова, где подробно рассматриваются источники, 
историография и основные этапы изучения истории и культуры горских евреев. Далее очерчивается история горских общин с VI в. и до окончания Второй мировой войны. Раздел заканчивается статьей Марка Куповецкого о динамике численности и расселении горских евреев с XIX до начала XX в. Третий раздел книги «Религия и традиционная культура» - самый большой и разнообразный, здесь представлены и статьи о традиционном религиозном образовании, и о письменной культуре, синагогах, кладбищах, традиционной музыке, фольклоре горских евреев. Большой интерес представляет пятый раздел «Горские евреи на трех континентах». Здесь собраны в том числе и статьи о современном состоянии горско-еврейских общин в Израиле и Азербайджане (Х. Брам), в США, Канаде, Германии, Австрии и России (С. Чарный).

Отдельно следует отметить оформление книги: собрано довольно большое количество фотографий конца XIX - начала XX вB. Помимо того, что многие статьи сопровождаются иллюстрациями, есть и отдельная подборка фотографий в конце книги. Для оформления обложки было использовано фото фрагмента ковра ручной работы, изготовленного мастерицей из Красной Слободы в 1950-е годы ХХ в. из фондов Историко-краеведческого музея г. Кубы́ (Азербайджан).

Стоит отметить, что есть и определенные пробелы: например, нет истории горских общин после 1945 г. Но это отмечают и сами редакторы в предисловии: «В книге, бесспорно, есть лакуны и пропуски, и она не даст вам абсолютно полного, всестороннего и всеобъемлющего описания нашей истории и всех аспектов культуры. Это дело будущего» (C. 11).

Данный труд, несомненно, стал важной вехой в исследовании горских евреев, он, с одной стороны, является некоторым итогом большого исследовательского проекта, с другой - он показывает перспективы дальнейших исследований этой группы евреев.

\title{
Литература
}

Горские евреи: История, этнография, культура / Сост. и ред. - В. Дымшиц; под общ. ред. И. Бегуна. М; Иерусалим: ДААТ / Знание, 1999. 464 с.

История и культура горских евреев / под. ред. Е.М. Назаровой, И.Г. Семенова. М: Всемирный конгресс горских евреев, 2018. 800 с.: ил.

\author{
Svetlana Amosova (Moscow, Russia) \\ Researcher, Institute of Slavic Studies, Russian Academy of Sciences \\ E-mail: sveta.amosova@gmail.com \\ ORCID: 0000-0001-7614-6549
}




\section{References}

Gorskie evrei: Istoriia, etnografiia, kul'tura / Sost. i red. - V. Dymshic; pod obsh'. red. I. Beguna. M; Ierusalim: DAAT / Znanie, 1999.

Istoriia i kul'tura gorskikh evreev / pod. red. E. Nazarovoi, I.G. Semenova. M: Vsemirnyi kongress gorskikh evreev, 2018. 